\title{
CASE REPORT \\ Central giant cell granuloma of the mandibular condyle: a case report and review of the literature
}

\author{
FM Jadu*, ${ }^{*}$, MJ Pharoah ${ }^{1}$, L Lee $^{2}$, GI Baker ${ }^{1,3}$ and A Allidina ${ }^{4}$ \\ ${ }^{1}$ Department of Oral and Maxillofacial Radiology, Faculty of Dentistry, The University of Toronto, Toronto, Canada; ${ }^{2}$ Dental \\ Clinic, Princess Margaret Hospital, Toronto, Canada, ${ }^{3}$ Oral and Maxillofacial Surgery, Department of Dentistry, Mount Sinai \\ Hospital, Toronto, Canada; ${ }^{4}$ General Dentistry, Department of Dentistry, Mount Sinai Hospital, Toronto, Canada
}

Central giant cell granuloma (CGCG) is a benign intraosseous lesion. The true nature of this lesion is controversial and remains unknown; the three competing theories are that it could be a reactive lesion, a developmental anomaly or a benign neoplasm. Furthermore, the actual aetiology of CGCG is still unclear, although inflammation, haemorrhage and local trauma have all been suggested; it has also been hypothesized that CGCG may have a genetic aetiology. Lesions central to the mandibular condylar head are very rare, with only three documented cases in the English language literature, none of which elaborates on the CT features.

In this case report, a 31-year-old male patient complaining of a left pre-auricular mass underwent radiographic investigation. CT images revealed a lesion central to the mandibular condyle and demonstrated features that were highly suggestive of CGCG. The patient underwent surgical curettage, and the subsequent histopathological examination confirmed the diagnosis of CGCG. 3 years after the procedure the patient presented with a recurrence and underwent complete resection of the mandibular condyle with immediate reconstruction. This report presents CT characteristics of a rare occurrence of CGCG of the mandibular condyle, compares it with other published cases and poses the question of the role of radiology in predicting the degree of aggressive behaviour of these lesions before surgery.

Dentomaxillofacial Radiology (2011) 40, 60-64. doi: 10.1259/dmfr/85668294

Keywords: granuloma; giant cell; giant cell granuloma; jaw diseases

\section{Introduction}

Central giant cell granuloma (CGCG) is a benign intraosseous lesion first described by Jaffe in $1953 .{ }^{1}$ The true nature of this lesion is controversial and remains unknown; the three competing theories are that it could be a reactive lesion, a developmental anomaly or a benign neoplasm. ${ }^{2-4}$ Neville et $\mathrm{al}^{5}$ consider this entity to be a non-neoplastic lesion and the World Health Organization $(\mathrm{WHO})^{6}$ classifies it as a bone-related lesion, not a tumour, although its clinical behaviour and radiographic features often are those associated with a benign tumour. Another controversial issue is the relationship of CGCG of the jaws to the giant cell tumour that occurs in extragnathic locations. ${ }^{7}$ Some authors regard the two as

\footnotetext{
*Correspondence to: Fatima M Jadu, Department of Oral and Maxillofacial Radiology, Faculty of Dentistry, The University of Toronto, 124 Edward Street, Office 350A, Ontario, M5G 1G6, Toronto, Canada; E-mail: fatima.jadu@dentistry.utoronto.ca

Received 30 August 2009; revised 16 November 2009; accepted 23 November
} 2009 different expressions of the same disease process, while others consider them two separate entities. ${ }^{8-10}$

Histologically, the features of CGCG are indistinguishable from the brown tumour of hyperparathyroidism and from giant cell lesions of genetic disorders such as cherubism, Noonan syndrome and neurofibromatosis Type $1 .^{11,12}$ Because of this histological similarity, it has been hypothesized that CGCG may have a genetic aetiology, ${ }^{12}$ although there is no convincing evidence to support this hypothesis. Using DNA microarray of surgically resected CGCG specimens, Carinci et $\mathrm{al}^{4}$ found several up- and downregulated genes that span a number of cellular functions including cell cycle regulation, signalling transduction and vesicular transport; however, the authors failed to identify the cell type. They speculated that products of these genes may be used as markers that could potentially help to characterize the clinical behaviour of specific lesions, or as therapeutic disease specific targets. 
Table 1 Comparison of the published cases of central giant cell granuloma central to the mandibular condyle

\begin{tabular}{|c|c|c|c|c|}
\hline & Shensa et al ${ }^{18} 1978$ & Tasanen et al ${ }^{17} 1978$ & Abu-El-Naaj et al 2002 & Current study 2011 \\
\hline Number of patients & 1 & 1 & 1 & 1 \\
\hline $\begin{array}{l}\text { Age in years at time of } \\
\text { initial presentation }\end{array}$ & 15 & 59 & 15 & 31 \\
\hline Gender & Male & Male & Female & Male \\
\hline Symptoms & Asymptomatic & $\begin{array}{l}\text { Painless slow-growing } \\
\text { pre-auricular swelling }\end{array}$ & Painless swelling & $\begin{array}{l}\text { Painful slow-growing } \\
\text { pre-auricular swelling }\end{array}$ \\
\hline Imaging type & $\begin{array}{l}\text { Panoramic, } \\
\text { laminagraphy }\end{array}$ & Laminagraphy & Panoramic, CT & Conventional, CT \\
\hline Imaging features & $\begin{array}{l}\text { Well defined, radiolucent, } \\
\text { expansile }\end{array}$ & Multilocular tumour & $\begin{array}{l}\text { Well defined, } \\
\text { corticated, expansile }\end{array}$ & $\begin{array}{l}\text { Well defined, expansile } \\
\text { with a granular bone } \\
\text { pattern }\end{array}$ \\
\hline Management & Enucleation & $\begin{array}{l}\text { Resection with costochondral } \\
\text { reconstructon }\end{array}$ & Enucleation & $\begin{array}{l}\text { Enucleation then resection } \\
\text { after recurrence }\end{array}$ \\
\hline Follow-up time & NA & 21 months & 6 months & 4 years \\
\hline
\end{tabular}

The incidence of CGCG in the general population is estimated to be $0.0001 \% .{ }^{13} 60 \%$ of cases occur before the age of $30.3,5$ Gender predilection reports are variable, but the majority occur in females with a female-male ratio of approximately $2: 1 .^{3,5}$ It has been noted that the development of CGCG occasionally coincides with the onset of pregnancy or menarche. ${ }^{7,14,15}$ Lesions develop twice as often in the mandible with an epicentre anterior to the first molar in young patients and there is a tendency for the epicentre to occur in the posterior aspect of the jaws after the first two decades of life. ${ }^{2,16}$ In the maxilla, the epicentre is more commonly anterior to the canine. ${ }^{2}$ Lesions that have originated in the mandibular condylar head, as opposed to lesions extending into the condylar head, are very rare, with few documented cases in the English language literature, none of which includes a detailed description of the CT features. ${ }^{3,17,18}$ A comparison of the published cases is presented in Table 1. This report details the clinical and $\mathrm{CT}$ features of a rare recurring CGCG central to the mandibular condyle.

\section{Case report}

A 31-year-old male patient complaining of a left preauricular mass was referred to the oral and maxillofacial radiology service at the Faculty of Dentistry, University of Toronto, in 2005. The patient complained of a lump that had gradually increased in size over the past 2 years. It was first noticed after the extraction of the maxillary left third molar and was associated with dull aching pain and a progressive limitation in mouth-opening. Extraoral examination revealed a firm round nodular swelling measuring $2 \mathrm{~cm}$ in diameter overlying the left temporomandibular joint (TMJ). This region was tender to palpation, but there was no associated lymphadenopathy.

Conventional radiographs (panoramic radiograph and open Towne's skull view) were made and CT images of the TMJ were acquired. The images demonstrated a lesion occupying the left condylar head and neck. The lesion was considerably expansile with segments of the expanded regions bordered by a well-defined cortex and some regions bordered with an ill-defined granular bone periphery. Of note was a lack of invasion into the

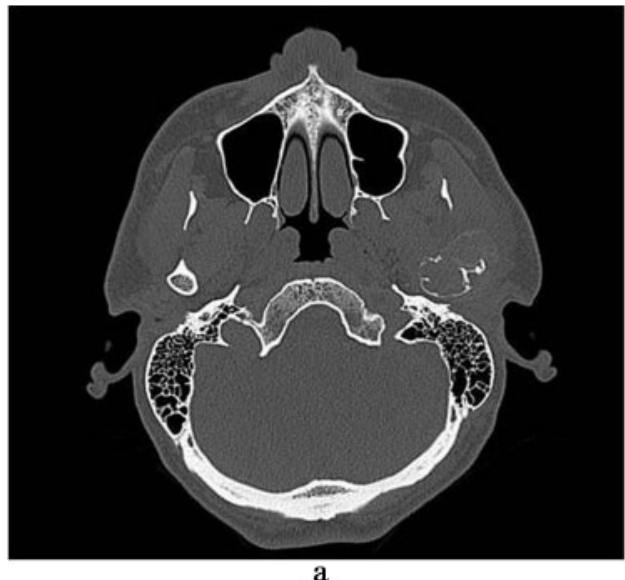

a

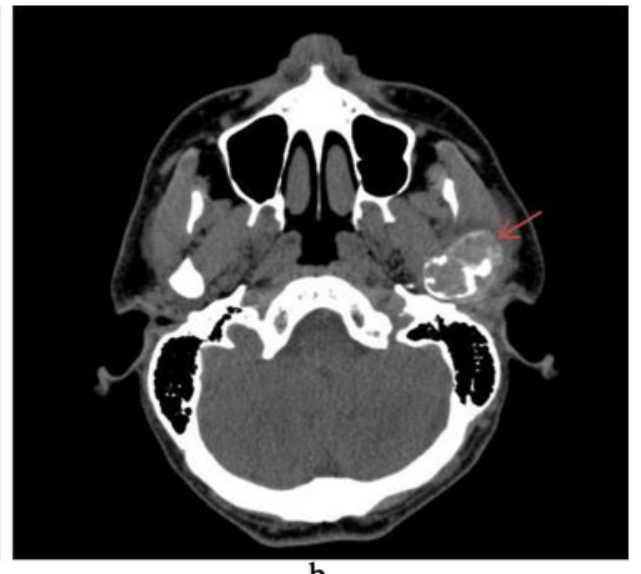

Figure 1 (a) Bone and (b) soft-tissue algorithm. Axial CT images showing an expansile, corticated lesion with an undulating border and a granular bone pattern laterally (arrow) 


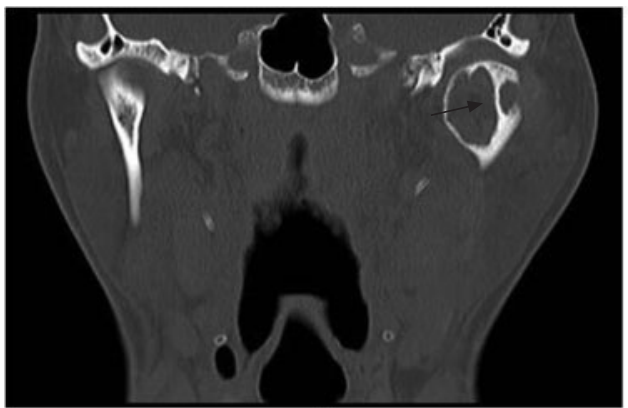

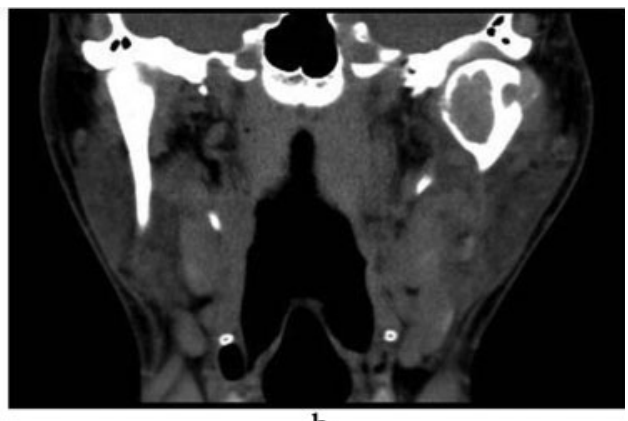

b

Figure 2 Reformatted coronal images in (a) bone and (b) soft-tissue algorithm showing the straight coarse septa (arrow) within the lesion and the remodelling of the mandibular fossa to accommodate the enlarged condyle

surrounding soft tissues. Internally, the lesion had a mixed density with a fine granular bone pattern especially in the lateral aspect of the lesion (Figure 1). There was a mixture of straight and coarse septa mixed with subtle and wispy septa (Figure 2). These features are characteristic of a CGCG. Remodelling of the mandibular fossa, to accommodate the enlarged condylar head, was also noted. Additionally, the enlarged condylar head assumed an inferior position within its fossa. The patient underwent an aggressive surgical curettage at another institution via a pre-auricular approach with dissection and sparing of all branches of the facial nerve. Subsequent histopathological examination showed curetted softtissue fragments consisting of a very cellular fibrous connective tissue stoma with numerous scattered multinucleated giant cells. There were deposits of haemosiderin and extravasated erythrocytes throughout (Figure 3). A diagnosis of CGCG was made.

There was resolution of the patient's symptoms until 2007. In 2008 the patient was referred to the oral and maxillofacial surgery service at Mount Sinai Hospital for the treatment of a recurrence. Clinical examination revealed facial asymmetry with an indurated, nontender $3.5 \mathrm{~cm}$ diameter swelling in the left pre-auricular region. CT imaging of the TMJ revealed enlargement of the original lesion and an increase in the granular pattern (Figure 4). The lesion was treated with a wide surgical resection of the mandibular condyle and immediate reconstruction of the joint using the TMJ replacement system (Biomet Microfixation,
Jacksonville, FL). The entire tissue mass was sent for pathological examination and the findings were identical to those seen in 2005; the diagnosis of recurrent CGCG was thus confirmed. Brown tumour of hyperparathyroid disease was excluded because normal levels of parathyroid hormone, plasma phosphate, calcium and total protein were detected.

\section{Discussion}

Chuong et $\mathrm{al}^{19}$ in 1986 and Ficarra et $\mathrm{al}^{20}$ in 1987 suggested categorizing CGCG into aggressive and nonaggressive types based on their clinical and radiographic characteristics. The more common, non-aggressive, lesions grew slowly and usually presented clinically as painless swellings, with only $20 \%$ of patients complaining of pain or parasthesia. ${ }^{3,5}$ Radiographically they appeared as well-defined unilocular or multilocular radiolucencies with undulating borders. ${ }^{2}$ Aggressive lesions were encountered in a younger patient population and tended to grow faster and recur more often. ${ }^{3}$ The greater growth rate of these lesions was evident radiographically as ill-defined borders with variable amounts of cortical destruction. This is especially true for lesions involving the maxilla., ${ }^{2,3}$

An imaging feature that has been associated with CGCG, but not mentioned in the reviewed case reports, is the presence of a subtle granular bone pattern at the periphery of the expanded bone. ${ }^{2}$ This
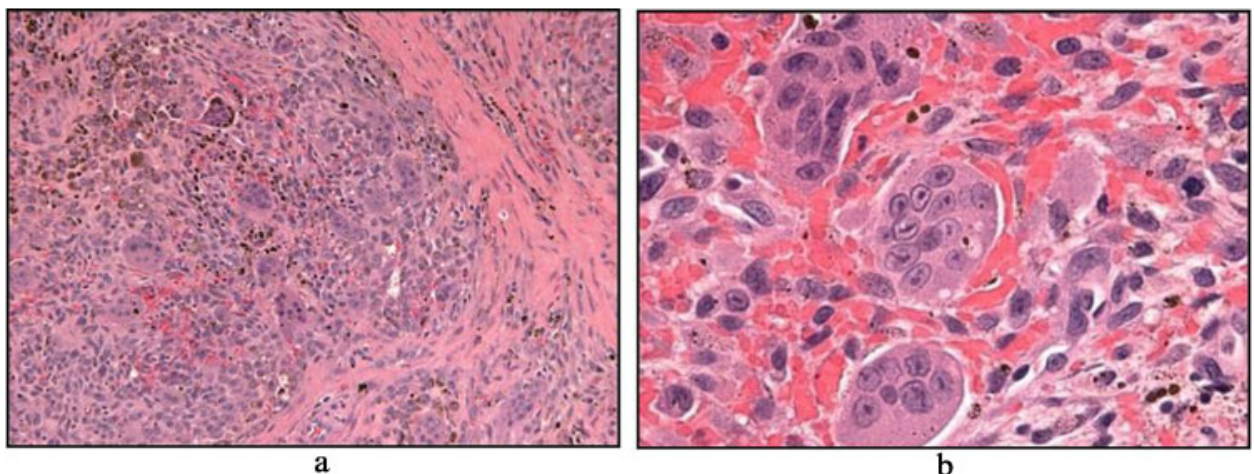

Figure 3 Photomicrographs at (a) $400 \times$ and (b) $1000 \times$ of haematoxylin- and eosin-stained slides showing sheets of (a) stromal cells and (b) multinucleated giant cells 

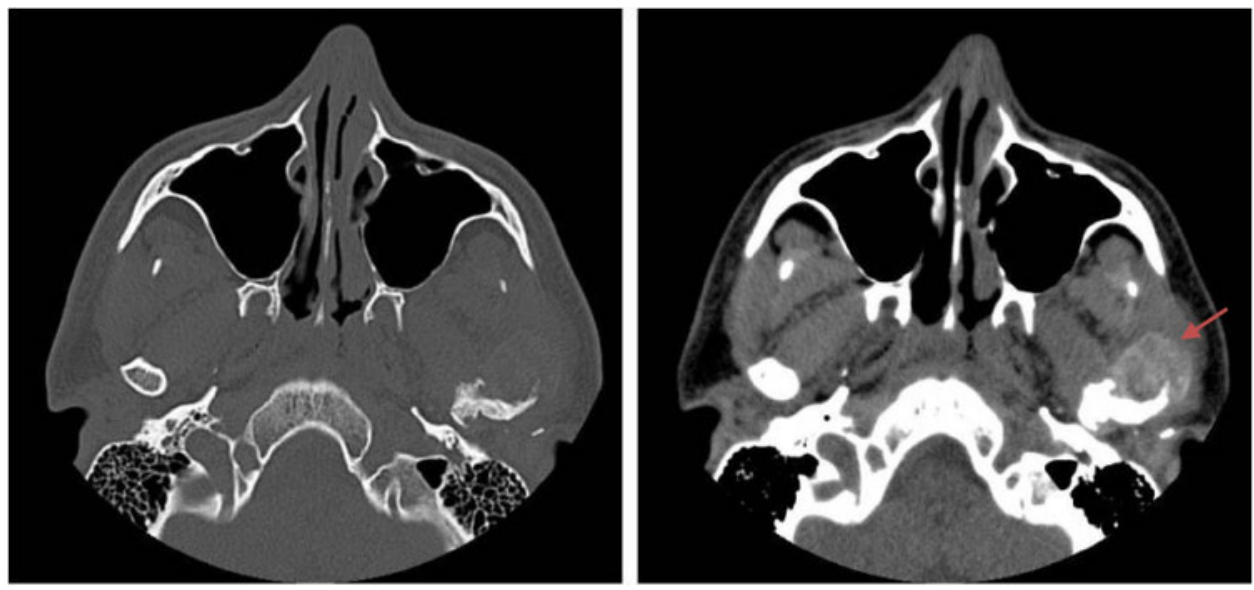

Figure 4 (a) Bone and (b) soft-tissue algorithm axial CT images demonstrating the larger recurrent lesion with copious granular bone pattern laterally (arrow)

characteristic is subtle and more prominent in the softtissue algorithm CT images. The granular pattern may also be seen in some of the internal septa. ${ }^{2}$ These features were present in the case presented in this report. In the case report by Abu-el-Naaj et $\mathrm{al}^{3}$ they provided axial CT (soft-tissue algorithm) and coronal CT (bone algorithm) images. They described the lesion as well defined and expansile; however, they did not comment on the granular pattern of the expanded cortex visible in the coronal CT image.

There are few documented cases of CGCG central to the mandibular condyle available in the English language literature. Table 1 presents a summary of these cases. Patient age at the time of presentation ranged between 15 and 59 years (mean 30 years). Interestingly, the gender distribution demonstrated a male predominance of $3: 1$; however, this is only based on four cases. The present case report is the only one that presented with clinical symptoms of pain. Two of the reported cases are likely to have been non-aggressive because they were treated with enucleation only, while the other two appear to have been more aggressive and were treated with resection.

Treatment of CGCG ranges from curettage to resection. Intralesional injections of corticosteroids have been used successfully, as has the systemic administration of calcitonin in the form of subcutaneous injections or nasal spray. ${ }^{11,21,22}$ Recurrence rates

\section{References}

1. Jaffe H. Giant-cell reparative granuloma, traumatic bone cyst, and fibrous (fibro-oseous) dysplasia of the jawbones. Oral Surg Oral Med Oral Pathol 1953; 6: 159-175.

2. White S, Pharoah M. Diseases of bone manifested in the jaws. In: White $\mathrm{S}$ and Pharoah M. Oral radiology: principles and interpretation ( $5^{\text {th }}$ edn). St. Louis, MO: Mosby, 2004: 501-503.

3. Abu-El-Naaj I, Ardekian L, Liberman R, Peled M. Central giant cell granuloma of the mandibular condyle: a rare presentation. J Oral Maxillofac Surg 2002; 60: 939-941.

4. Carinci F, Piattelli A, Martinelli M, Palmieri A, Rubini C, Fioroni M, et al. Genetic profiling of central giant cell granuloma of the jaws. J Craniofac Surg 2005; 3: 399-407. have been reported to range between $11 \%$ and $49 \% .^{16}$ This wide range is attributed to the spectrum of lesions that extends from the more common small painless non-aggressive lesion to the less common large painful and aggressive lesion. ${ }^{16}$ Thus, aggressive lesions, such as the one presented in this report, should be managed by complete surgical resection to decrease the risk of recurrence. The difficulty, however, lies in determining the degree of aggressive behaviour before surgery.

In conclusion, the differential diagnosis of preauricular masses includes a long list of conditions ranging from normal variations, such as the accessory lobe of the parotid gland, to neoplasms involving any of a number of structures in the area. This report presents imaging characteristics of a rare occurrence of CGCG of the mandibular condyle. The presence of a granular bone pattern both at the expanded periphery and as part of the internal septa is characteristic of CGCG. Unfortunately, a detailed comparison of the imaging characteristics of the other three reported cases is not possible owing to the lack of detailed descriptions in the published reports. A review of the diagnostic imaging characteristics is required, preferably including $\mathrm{CT}$ images of a significant number of well documented cases of CGCG; this should be correlated with the behaviour of each case to determine whether the degree of aggressive behaviour can be predicted by the imaging characteristics.

5. Neville B, Damm D, Allen C, Bouquot J. Bone pathology. In: Oral and maxillofacial pathology $\left(2^{\text {nd }}\right.$ edn). Philadelphia, PA: W.B. Saunders Company, 2002: 544-547.

6. Jundt G. Central giant cell lesion. In: Barnes L, Eveson JW, Reichart P, Sidransky D, editors. World Health Organization Classification of tumours pathology and genetics of head and neck tumours. Lyon: IARC Press, 2005: 324.

7. Allen D, Sheats R. A central giant cell granuloma in a patient seeking orthodontic treatment. J Am Dent Assoc 2001; 132: 1255-1260.

8. Abrams B, Shear M. A histological comparison of the giant cells in the central giant cell granuloma of the jaws and the giant cell tumour of long bone. J Oral Pathol Med 1974; 3: 217-223. 
9. Waldron C, Shafer W. The central giant cell reparative granuloma of the jaws. An analysis of 38 cases. Am J Clin Pathol 1966; 45: 437-447.

10. Kauzman A, Li SQ, Bradley G, Bell RS, Wunder JS, Kandel R. Central giant cell granuloma of the jaws: assessment of cell cycle proteins. J Oral Pathol Med 2004; 33: 170-176.

11. de Lange J, van den Akker HP, van den Berg H. Central giant cell granuloma of the jaw: a review of the literature with emphasis on therapy options. Oral Surg Oral Med Oral Pathol Oral Radiol Endod 2007; 104: 603-615.

12. de Lange J, van Maarle MC, van den Akker HP, Redeker EJ. DNA analysis of the SH3BP2 gene in patients with aggressive central giant cell granuloma. Br J Oral Maxillofac Surg 2007; 45: 499-500.

13. de Lange J, van den Akker HP, Klip H. Incidence and diseasefree survival after surgical therapy of central giant cell granulomas of the jaw in The Netherlands: 1990-1995. Head Neck 2004; 26: 792-795.

14. Fechner RE, Fitz-Hugh GS, Pope TJ Jr. Extraordinary growth of giant cell reparative granuloma during pregnancy. Arch Otolaryngol 1984; 110: 116-119.
15. Horner K. Central giant cell granuloma of the jaws: a clinicoradiological study. Clin Radiol 1989; 40: 622-626.

16. de Lange J, van den Akker HP. Clinical and radiological features of central giant-cell lesions of the jaw. Oral Surg Oral Med Oral Pathol Oral Radiol Endod 2005; 99: 464-470.

17. Tasanen A, von Konow L, Nordling. Central giant-cell lesion in the mandibular condyle. Report of a case. Oral Surg Oral Med Oral Pathol 1978; 45: 532-539.

18. Shensa D, Nasseri S. Central giant cell reparative granuloma of the mandibular condyle. J Oral Surg 1978; 36: 642-643.

19. Chuong R, Kaban L, Kozakewich H, Perez-Atayde A. Central giant cell lesions of the jaws: a clinicopathologic study. J Oral Maxillofac Surg 1986; 44: 708-713.

20. Ficarra G, Kaban L, Hansen L. Central giant cell lesions of the mandible and maxilla: a clinicopathologic and cytometric study. Oral Surg Oral Med Oral Pathol 1987; 64: 44-49.

21. Carlos R, Sedano H. Intralesional corticosteroids as an alternative treatment for central giant cell granuloma. Oral Surg Oral Med Oral Pathol Oral Radiol Endod 2002; 93: 161-166.

22. Harris M. Central giant cell granulomas of the jaws regress with calcitonin therapy. Br J Oral Maxillofac Surg 1993; 31: 89-94. 